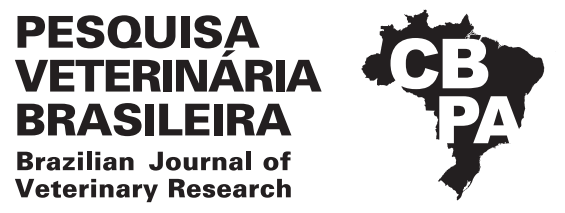

Pesq. Vet. Bras. 39(6):376-381, June 2019 DOI: 10.1590/1678-5150-PVB-6072

Original Article

ISSN 0100-736X (Print)

Livestock Diseases

ISSN 1678-5150 (Online)

\title{
Polioencephalomalacia (PEM) in calves associated with excess sulfur intake ${ }^{1}$
}

\author{
Jéssica A. Withoeft ${ }^{2,3}$, Gustavo R. Bonatto ${ }^{2,3}$, Isadora C. Melo ${ }^{2,3}$, \\ Deise Hemckmeier ${ }^{4}$, Leonardo S. Costa ${ }^{2,5}$, Thierry G. Cristo ${ }^{2,5}$, Nara L. Pisetta ${ }^{6}$ \\ and Renata A. Casagrande ${ }^{2 *}$ (D)
}

\begin{abstract}
Withoeft J.A., Bonatto G.R., Melo I.C., Hemckmeier D., Costa L.S., Cristo T.G., Pisetta N.L. \& Casagrande R.A. 2019. Polioencephalomalacia (PEM) in calves associated with excess sulfur intake. Pesquisa Veterinária Brasileira 39(6):376-381. Laboratório de Patologia Animal, Centro de Ciências Agroveterinárias, Universidade do Estado de Santa Catarina, Av. Luís de Camões 2090, Conta Dinheiro, Lages, SC 88520-000, Brazil. E-mail: renata.casagrande@udesc.br

Polioencephalomalacia (PEM) is the morphological characterization for softening of brain gray matter, and excess sulfur intake is one of its main causes. This study describes an outbreak of this disease in 1-to-3-month-old calves in a farm located in Santa Catarina state, Brazil. The herd consisted of 27 Jersey male calves whose diet was composed of initial feed, ground whole corn, and mineral salt. From this herd, 10 animals became ill, showing signs of apathy, anorexia and blindness, evolving to generalized weakness and death. Necropsy was performed in three of these animals, which showed flattening of the cerebral convolutions in addition to softened, yellowish areas in the cerebral cortex. Histopathological examination revealed deep laminar necrosis associated with perineuronal and perivascular edema, as well as neurons with wrinkled, eosinophilic, or vacuolated cytoplasm. The following sulfur doses were observed: $8,010 \mathrm{mg} / \mathrm{kg}$ in corn, $6,385 \mathrm{mg} / \mathrm{kg}$ in initial feed, $1,060 \mathrm{mg} / \mathrm{kg}$ in mineral salt and $2.3 \mathrm{mg} / \mathrm{L}$ in water, reaching dose values far above the accepted, totaling a daily intake of approximately $6,533.5 \mathrm{mg}$ sulfur/animal/day. As differential diagnosis, lead was dosed in the kidneys and liver of the three calves, with negative results. Also, the calf that sickened last was treated with $20 \mathrm{mg} / \mathrm{kg}$ thiamin and $0.2 \mathrm{mg} / \mathrm{kg}$ dexamethasone (IM; QID) for three days and eventually recovered. According to anatomopathological findings, excess sulfur intake and therapeutic diagnosis, sulfur poisoning was suggested as the cause of PEM in these 1-to-3-month-old calves. Occurrence of PEM is rare in calves at such a young age.
\end{abstract}

INDEX TERMS: Polioencephalomalacia, calves, excess sulfur intake, sulfur, neurological diseases, thiamin, ruminants, cattle, pathology.

\footnotetext{
${ }^{1}$ Received on February 13, 2019.

Accepted for publication on February 25, 2019.

${ }^{2}$ Laboratório de Patologia Animal, Centro de Ciências Agroveterinárias, Universidade do Estado de Santa Catarina (UDESC), Av. Luís de Camões 2090, Bairro Conta Dinheiro, Lages, SC 88520-000, Brazil. *Corresponding author: renata.casagrande@udesc.br

${ }^{3}$ Veterinary Medicine Course, Centro de Ciências Agroveterinárias, Universidade do Estado de Santa Catarina (UDESC), Av. Luís de Camões 2090, Bairro Conta Dinheiro, Lages, SC 88520-000.

${ }^{4}$ Veterinarian, Prefeitura de Pouso Redondo, Rua Antônio Carlos Thiesen 74, Centro, Pouso Redondo, SC 89172-000, Brazil.

${ }^{5}$ Postgraduate Program in Animal Science, Centro de Ciências Agroveterinárias, Universidade do Estado de Santa Catarina (UDESC), Av. Luís de Camões 2090, Bairro Conta Dinheiro, Lages, SC 88520-000.

${ }^{6}$ Veterinarian, Fábrica de Laticínios Predileto ${ }^{\circledR}$, Rua Castelo Branco 1975, Pouso Redondo, SC 89172-000.
}

RESUMO.- [Polioencefalomalacia em bezerros associada à ingestão de alimento com excesso de enxofre.] A polioencefalomalacia (PEM) é a caracterização morfológica para o amolecimento da substância cinzenta encefálica, e uma de suas principais etiologias é a ingestão excessiva de enxofre. Este trabalho descreve um surto desta enfermidade em bezerros de um a três meses de idade em uma propriedade de Santa Catarina. O lote era composto por 27 bezerros machos da raça Jersey, com alimentação composta por ração inicial, milho inteiro triturado e sal mineral. Deste lote, 10 animais adoeceram, apresentando sinais de apatia, anorexia e cegueira, com evolução para fraqueza generalizada. Nove bezerros morreram e três foram submetidos a necropsia, 
que demonstraram achatamento das circunvoluções cerebrais além de áreas de amolecimento e coloração amarelada no córtex cerebral. Realizou-se exame histopatológico que evidenciou necrose laminar profunda associada a edema perineuronal e perivascular, além de neurônios com citoplasma enrugado, eosinofílico ou vacuolizado. A dosagem de enxofre resultou em $8010 \mathrm{mg} / \mathrm{Kg}$ no milho, $6385 \mathrm{mg} / \mathrm{Kg}$ na ração, $1060 \mathrm{mg} / \mathrm{Kg}$ no sal mineral e $2,3 \mathrm{mg} / \mathrm{L}$ na água, atingindo valores muito acima do tolerado, totalizando a ingestão diária de cerca de $6533,5 \mathrm{mg}$ de enxofre/animal/dia. Como diagnóstico diferencial realizou-se dosagem de chumbo de amostras de rim e fígado dos três bezerros com resultado negativo. Ainda, o último bovino a adoecer foi tratado com $20 \mathrm{mg} / \mathrm{Kg}$ de tiamina e $0,2 \mathrm{mg} / \mathrm{Kg}$ de dexametasona IM, QID, durante três dias e recuperou-se. De acordo com os achados anatomopatológicos e o excesso de enxofre na dieta, sugere-se que a intoxicação por enxofre seja a causa de PEM nestes bezerros de um a três meses de idade, sendo essa enfermidade rara em bovinos tão jovens.

TERMOS DE INDEXAÇÃO: Polioencefalomalacia, bezerros, enxofre, doenças neurológicas, tiamina, ruminantes, bovinos, patologia.

\section{INTRODUCTION}

Polioencephalomalacia (PEM) is the morphological characterization for softening (malacia) of brain gray matter (Cunha et al. 2010). Until 1970, this term was believed to represent not only a lesion, but also a disease specific of ruminants associated with thiamine deficiency, characterized by necrosis of the brain cortex (Adams et al. 1956). However, many studies have reported multiple etiologies for cerebrocortical necrosis, such as poisoning with sodium chloride associated with water deprivation (Scarratt et al. 1985), lead poisoning (Traverso et al. 2004), infection with bovine herpesvirus type 5 (BoHV-5) (Cagnini et al. 2015), ingestion of thiamine-rich plants (Ramos et al. 2005), and amprolium (Nogueira et al. 2010) and sulfur (Gould 2000, Kul et al. 2006) poisonings.

Sulfur poisoning is an important cause of PEM, in addition to being common in bovines (Gould 2000, Niles et al. 2000, Traverso et al. 2001, Haydock 2003, Kul et al. 2006, McKenzie et al. 2009). Approximately $0.2 \%$ of sulfur can be found in the animal body, which is originated mainly from sulfur-containing amino acids (cystine, cysteine and methionine) and vitamins (biotin and thymine), and ruminal fermentation is the main form of sulfur transformation (Ortolani 2001). Thus, PEM outbreaks related to this etiology are associated with high levels of sulfate, sulfite or sulfide sulfur in feed (Traverso et al. 2001) or water (Gould 2000). Sources of these compounds are variable, including feed additives and pastures rich or contaminated with this element; however, the most common source is water (Olkowski 1997).

PEM progresses with clinical signs that include neurological symptoms such as ataxia, blindness, dysphagia, depression and decubitus (Hamlen et al. 1993), and calves aged 6-9 months can die in 24-48 h (Radostits et al. 2002). In calves, this disease has been reproduced with corn gluten-based diets with high sulfur concentration (Niles et al. 2002), and it has been reported as a natural form in calves that ingested ryegrass (Lolium multiflorum) pasture with high contents of this element (Cunha et al. 2010). The present study aims to report a PEM outbreak in calves aged 1-3 months in Santa Catarina state and describe the clinical and anatomopathological changes, as well as the results of the total dose of sulfur in the diet of the investigated animals.

\section{MATERIALS AND METHODS}

Epidemiological and clinical data on PEM were obtained with the producer and veterinarian during the visit to the property. Three calves died of natural cause and were submitted to necropsy by the veterinary in charge. Samples of the following organs were collected: encephalon, spinal cord, trigeminal ganglion, pituitary gland, rete mirabile, heart, lung, pre-stomach, abomasum, kidneys, bladder, liver, spleen, lymph node, small and large intestines and fixed in $10 \%$ buffered formalin for routine histopathological processing and hematoxylin and eosin (HE) staining. Liver and kidneys were also sent to laboratory lead dosing using the atomic absorption spectrophotometry (AAS) method. Special Ziehl-Neelsen stain was performed in the kidneys to detect eosinophilic intra-nuclear inclusion bodies compatible with lead poisoning. Samples of feed, water, minerals and corn were collected for sulfur dosing using the inductively coupled plasma atomic emission spectrophotometry (ICP-AES) method.

\section{RESULTS}

The farm was located in the municipality of Pouso Redondo, region of the Alto Vale do Itajaí, Santa Catarina state, Brazil (2715'29" S; 4956'02" W). The herd was composed of 27 male Jersey calves aged 15-80 days with weight below the breed average ( 20 to $90 \mathrm{~kg}$ ). The animals were acquired as newborns from several properties, raised in a wooden shed of approximately $30 \mathrm{~m}^{2}$ with corn shavings and straw bedding. All animals lived together and had access to feed consisting of $15 \mathrm{~kg}$ of initial feed and $10 \mathrm{~kg}$ of ground whole corn (straw and cob), totalizing $25 \mathrm{~kg}$ of feed offered daily. $5 \times 0.4 \mathrm{~m}$ square feeder troughs were used, not allowing access of all animals at the same time. The property had four cows as dairy nurses, whose milk production varied from 8 to 10L/day, and only the youngest (10 to 12 animals) nursed once a day, whereas the remaining had only solid feed. In addition, mineral salt was freely available from 15 to 20 days of age. The corn used in the animal feed was produced in the property, with use of $250 \mathrm{~kg}$ of fertilizer and $150 \mathrm{~kg}$ of urea per hectare.

The producer reported that 10 out of the 27 animals sickened and 9 died between 1 and 3 months of age. Of the calves that died, four were nursing and the remainder were in exclusively solid feed. All animals showed clinical symptoms, including apathy, anorexia and blindness, and evolved to generalized weakness, decubitus, and death in 3 to 4 days. The last animal to sicken was treated with $20 \mathrm{mg} / \mathrm{kg}$ thiamine (Monovin $\mathrm{B} 1^{\circledR}$ ) and $0.2 \mathrm{mg} / \mathrm{kg}$ dexamethasone (Cortvet ${ }^{\circledR}$ ) (IM; QID) for 3 days and eventually recovered. Necropsy of the three calves revealed flattening of the brain convolutions and diffuse, softened, yellowish areas in the cerebral telencephalic cortex (Fig.1).

Cerebral microscopic lesions in the frontal cortex were characterized by deep laminar necrosis (Fig.2A), associated with perineuronal and perivascular edema, in addition to neurons with intensely eosinophilic cytoplasm, wrinkled or vacuolated (Fig.2B). The remaining organs did not show significant histological changes. Special Ziehl-Neelsen stain was performed, which was negative for the presence of intra-nuclear lead inclusion bodies in the renal tubules. Liver and kidney samples submitted to lead dosing also 
revealed negative results. Sulfur dosing for corn, initial feed, mineral salts, and water showed values of $8,010 \mathrm{mg} / \mathrm{kg}$, $6,385 \mathrm{mg} / \mathrm{kg}, 1,060 \mathrm{mg} / \mathrm{kg}$, and $2.3 \mathrm{mg} / \mathrm{L}$, respectively. The final sulfur contents in diet were $95,775 \mathrm{mg}$ in initial feed, $466.4 \mathrm{mg}$ in mineral salt (considering ingestion of $0.8 \%$ bodyweight), $80,100 \mathrm{mg}$ in ground corn, and $62.1 \mathrm{mg}$ in water (considering ingestion of $1 \mathrm{~L}$ of water/animal/day, expected for nursing calves up to 60 days of age in the bay). Thus, the total daily sulfur ingestion per animal was approximately 6,533.5mg.

\section{DISCUSSION}

According to Klasing et al. (2005), diet sulfur content $>3,000 \mathrm{mg} / \mathrm{kg}$ in dry matter may cause disease. In this study, the sulfur content was much higher than the maximum limit and contributed to evolution of the acute symptoms

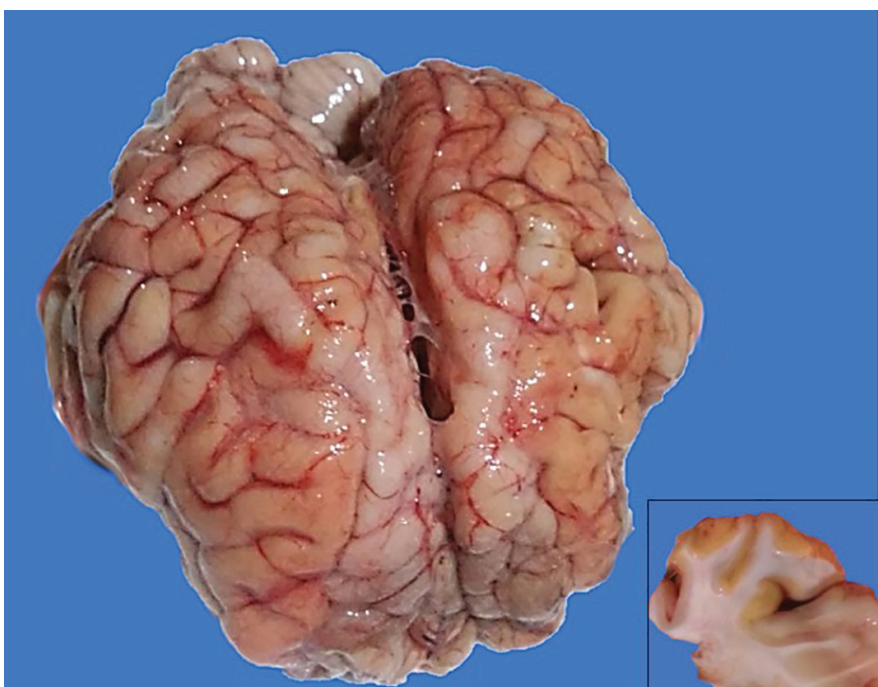

Fig.1. Polioencephalomalacia due to excess sulfur intake in calves. Brain with flattening of the convolutions and focally extensive yellowish areas in the cerebral cortex. Insert: cross section of the frontal cortex showing multiple yellowish areas in the gray matter.
(Sant'Ana et al. 2009b, Cunha et al. 2010). In addition, poisoning occurred in very young calves that did not have the ruminal microbiota completely developed and fed exclusively on feed. Moreover, the use of ground corn with high sulfur content was the main trigger for PEM because high starch content diets favor decreased ruminal $\mathrm{pH}$ due to changes in the microbiota. Predominance of amidolytic bacteria with faster carbohydrate fermentation causes accumulation of organic acids in the liver, which becomes a favorable environment for production of sulfuric gas, surpassing the liver oxidation capacity, thus contributing to the action of this compound in the central nervous system (CNS) (Sager et al. 1990, Gould et al. 1991). PEM associated with excess sulfur intake can display two clinical forms: in the acute form, animals evolve to death in most cases, preceded by blindness, convulsions, opisthotonus, head pressure against objects and decubitus (Gould 2000), lasting usually two to four days (Sant'Ana et al. 2009b), whereas in the subacute form, animals usually evolve to recovery with mild neurological deficit (Gould 2000). A chronic form of $\mathrm{PEM}$ has been reported in cattle with up to 25 days of clinical course (Gonçalves et al. 2001).

The gross and microscopic lesions observed in the brain of the three investigated calves were similar to those described in a different PEM outbreak caused by excess sulfur intake, with swelling and flattening of the cerebral convolutions, microscopically characterized by laminar necrosis of the cerebral cortex associated with perivascular and perineuronal edema and vacuolated, wrinkled and eosinophilic cytoplasmic neurons (Cunha et al. 2010). Other microscopic lesions commonly observed in bovines with PEM include proliferation of blood vessels with swelling of endothelial cells in the brain, in addition to mononuclear inflammatory infiltrate and presence of Gitter cells (Nakazato et al. 2000). Gitter cells are more commonly found in subacute or chronic cases, and may also show loss of the telencephalic cortex (Moro et al. 1994). However, these changes were not evidenced in this study probably due to the short clinical course. Cases in which the disease evolves quickly may present edema only,
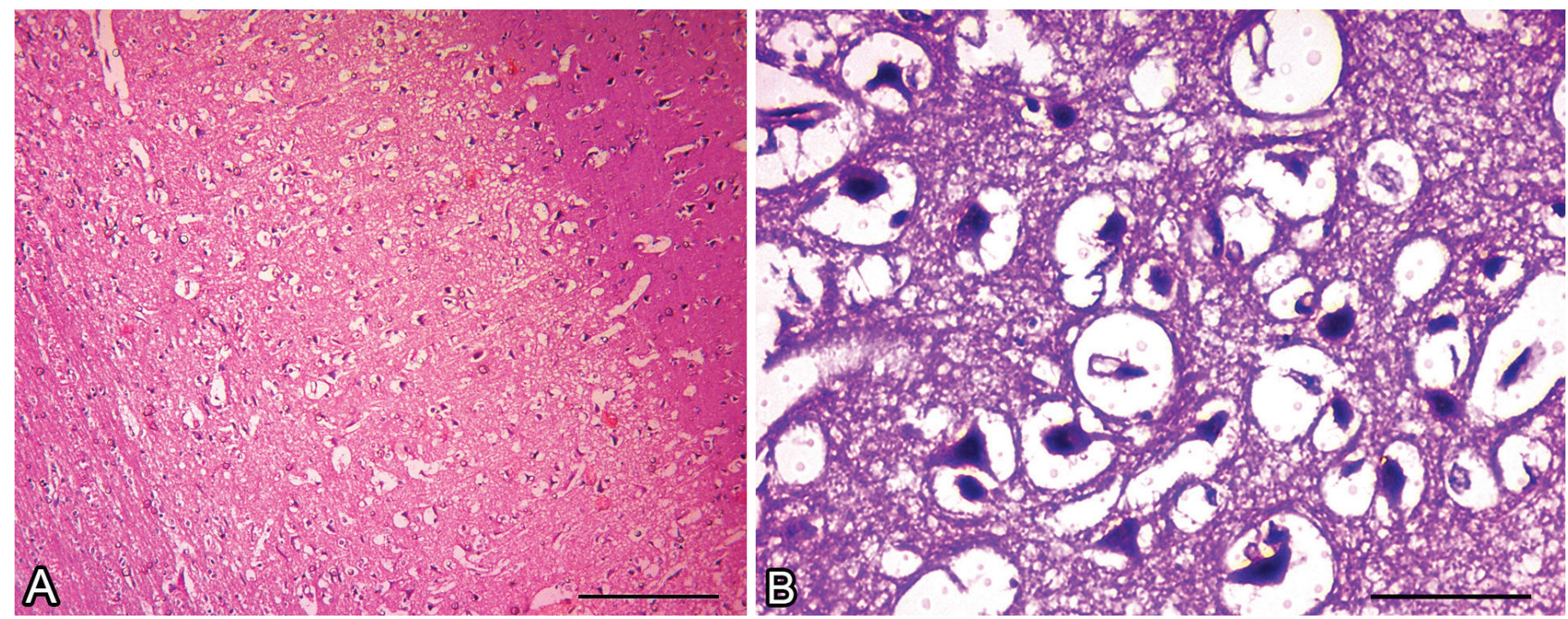

Fig.2. Polioencephalomalacia due to excess sulfur intake in calves. (A) Brain with deep laminar cortical necrosis associated with perineuronal, perivascular and neuropilic edema. HE, bar $=100 \mu \mathrm{m}$. (B) Neurons with wrinkled cytoplasm and perineuronal edema. $\mathrm{HE}$, bar $=20 \mu \mathrm{m}$. 
leading to brain swelling, or even showing no characteristic findings (Nakazato et al. 2000). In some cases, brain edema is accentuated to the point that it leads to cerebellar and bulb herniation through the foramen magnum (Moro et al. 1994). Focal hemorrhages of the thalamus and midbrain were also observed in bovines naturally poisoned with sulfur (Loneragan et al. 1998). Lesion pattern characterized by cortical neuronal necrosis in addition to lesions in the ventral structures of the brain suggest that PEM was caused by sulfur poisoning (Jeffrey et al. 1994); however, the pattern suggested in previous reports was not verified in the present study because, due to the short clinical course, there was not enough time for the development of those lesions.

It is important to take different aspects into account in order to exclude other neurological diseases and causes of PEM, such as thiamine deficiency, which occurs mainly in animals submitted to carbohydrate-rich and low-fiber diets, or changes from poor to good quality pasture (Adams et al. 1956). This occurs because carbohydrate-rich diets ferment quickly and reduce the ruminal $\mathrm{pH}$, leading to a case of ruminal lactic acidosis, which impairs the growth of thiamine-synthetizing microorganisms and favors multiplication of thiaminase-producing bacteria (Haven et al. 1983). Even though the diet of the animals involved in this outbreak already contained concentrate, it also showed high fiber content; therefore, signs of ruminal lactic acidosis were not observed at necropsy and in histological analysis of the rumen. Thus, in young animals, the most common manifestation is primary thiamine deficiency, when not present in enough quantity in the diet. This occurs because animals are not yet able to synthesize this vitamin (Ferreira et al. 1986), and primary deficiency should not be excluded as a PEM-related factor in addition to elemental sulfur toxicosis. Epidemiologically, sulfur poisoning can occur in young or adult animals, depending on the age of the animal exposed to excess of this element (Jeffrey et al. 1994). This aspect is also observed in cases of sodium chloride poisoning (Pearson \& Kallfelz 1982); however, in this case, in addition to the microscopic lesions characteristic of PEM, sub-meningeal eosinophilic infiltrate is commonly observed in the Virchow-Robin spaces, or even in the neuropile (Lemos et al. 1997). Cases of lead poisoning usually occur when herds are exposed to pastures containing industrial waste with this metal. The bovine species is the most affected due to lower selectivity of eating habits (Traverso et al. 2004). Bovines with lead poisoning show, in addition to concentrations of approximately $10 \mathrm{ppm}$ in the liver and kidneys (Riet-Correa et al. 2007), degeneration of the kidney tubular epithelium associated with eosinophilic intra-nuclear inclusion bodies evidenced by special Ziehl-Neelsen stain (Traverso et al. 2004). Young bovines submitted to stressful and immunosuppressant situations can develop PEM due to BoHV-5 meningoencephalitis, and normally exhibit perivascular cuffs composed of mononuclear cells, as well as basophilic intra-nuclear inclusion bodies in astrocytes and neurons (Rissi et al. 2006). Cattle experimentally submitted to amprolium poisoning, a thiamine antagonist, showed hemorrhages in the gastrointestinal tract, skin, trachea, subcutis, endocardium and bladder, also visualized microscopically; in addition to the PEM characteristic lesion in the brain, they showed neutrophilic infiltrate in vessels of the leptomeninge in the parietal telencephalon (Nogueira et al. 2010).
Water, mineral salt, pasture and concentrate are important sources of sulfur. Sulfur concentrations $>0.4 \%$ in the diet may result in cerebrocortical necrosis. Thus, sulfur must be quantified in all diet components as one of the diagnostic tools for excess sulfur intake PEM (Sant'Ana et al. 2009a), as performed during this outbreak. Bacteria of the genera Desulfotomaculum sp. and Desulfovibrio sp. are essential to sulfur metabolism. They are responsible for its degradation into sulfuric gas, which is a normal sulfur metabolite absorbed or eructed by the animal (Burgess 2008). However, when present at high levels, the ruminal mucosa absorbs it in excess and inhibits the oxidative process of adenosine triphosphate (ATP) production by blocking carbonic anhydrase, catalase, peroxidase, and dehydrogenase. Furthermore, sulfides also act by forming sulfahemoglobin, which has low oxygen transport ability (Bulgin et al. 1996). Nervous tissue is formed by a large amount of lipids, increasing the susceptibility to damage due to intense oxidative metabolism. Thus, sulfur poisoning creates necrotic lesion by producing sulfate-derived radicals (Gould et al. 1991), compatible with the brain lesions visualized in these animals.

Dosing of ruminal hydrogen sulfide (sulfuric gas) assists with the diagnosis of PEM caused by excess sulfur intake, reaching values of 2,300 to $13,500 \mathrm{ppm}$ in ingestion of $0.9 \%$ sulfur (Loneragan et al. 1998) and 1,000 to 2,500ppm in ingestion of $0.38 \%$ of this element (Cunha et al. 2010) in a dry matter basis. In this outbreak, however, dosing was not possible because no animals with the clinical symptoms were alive by the time the farm was visited.

According to Cunha et al. (2011), dosing of this gas is also important in healthy animals exposed to diet with high sulfur contents, since animals already presenting clinical symptoms can show low indexes of hydrogen sulfide owing to anorexia. Considering the importance of sulfuric gas dosing for the diagnosis of PEM, its absence in the present study does not allow confirmation of sulfur toxicosis, but only suggests it. Water is an important source of sulfur poisoning, mainly in the hot seasons of the year, when there is increased consumption and evaporation, resulting in higher sulfate levels (Cunha et al. 2010). However, water was not the source of poisoning in this outbreak, as only levels $>200 \mathrm{mg} / \mathrm{L}$ can trigger PEM (Klasing et al. 2005). Milk has high levels of calcium and phosphorus and lower levels of the remaining minerals, such as sulfur (González 2001), and this concentration could not contribute to the disease. In the treatment of the animals, in addition to eliminating the source of feed containing excess sulfur, the therapeutic protocol with thiamine and dexamethasone was proven efficient, mainly in animals presenting initial symptoms of the disease. Nevertheless, although this combination was efficient in the present study, it has been shown to be inefficient in previous reports on excess sulfur intake involving ovine (Bulgin et al. 1996). Thiamine administration is important not only in cases of suspected deficiency of this vitamin, but also in those of sulfur toxicosis, since thiamine assists with eliminating the free radicals formed during the metabolism of sulfides and sulfites, protecting the brain tissue (Olkowski et al. 1992).

High doses of sulfur in animal feeding, the therapeutic protocol used in the surviving animal, the negative result for lead dosing in the kidneys and liver, and the absence of additional lesions suggestive of other diseases such as ruminal 
lactic acidosis, suggest excess sulfur intake as the cause of PEM in this study. This is an extremely important disease because it is a differential diagnosis for infectious neurological diseases such as rabies and BoHV-5 meningoencephalitis. It also leads to economic losses, requiring controlled handling of animal diet and supplementation.

\section{CONCLUSION}

Neurological clinical signs associated with the anatomopathological changes, excess sulfur intake, and the therapeutic diagnosis of the animals show that sulfur poisoning is the cause of polioencephalomalacia (PEM) in calves aged 1 to 3 months; this is a rare disease in calves at such a young age.

Conflict of interest statement. The authors declare no competing interests.

\section{REFERENCES}

Adams O.R., Griner L.A. \& Jensen R. 1956. Polioencephalomalacia of cattle and sheep. J. Am. Vet. Med. Assoc. 129(7):311-321. <PMid:13366824>

Bulgin M.S., Lincoln S.D. \& Mather G. 1996. Elemental sulfur toxicosis in a flock of sheep. J. Am. Vet. Med. Assoc. 208(7):1063-1065. <PMid:8621320>

Burgess B.A. 2008. Polioencephalomalacia. Large Anim. Vet. 8(8):1-6.

Cagnini D.Q., Cunha P.H.J., Pantoja J.C.F., Badial P.R., Oliveira-Filho J.P., Araújo-Junior J.P., Alfieri A.A. \& Borges A.S. 2015. Histopathological, immunohistochemical, and molecular study of BHV-5 infection in the central nervous system of experimentally infected calves. Pesq. Vet. Bras. 35(4):337-343. <http://dx.doi.org/10.1590/S0100-736X2015000400004>

Cunha P.H., Bandarra P.M., Dias M.M., Borges A.S. \& Driemeier D. 2010. Surto de polioencefalomalacia por ingestão excessiva de enxofre na dieta em bezerros no Rio Grande do Sul. Pesq. Vet. Bras. 30(8):613-617. <http:// dx.doi.org/10.1590/S0100-736X2010000800001>

Cunha P.H.J., Badial P.R., Cagnini D.Q., Oliveira-Filho J.P., Moares L.F., Takahira R.K., Amorim R.L. \& Borges A.S. 2011. Polioencefalomalacia experimental em bovinos induzida por toxicose por enxofre. Pesq. Vet. Bras. 31(1):41-52. <http://dx.doi.org/10.1590/S0100-736X2011000100007>

Ferreira F.A., Coelho H.E. \& Bastos J.E.D. 1986. Polioencefalomalacia em bovinos no estado de Minas Gerais. Arq. Bras. Med. Vet. Zootec. 38:693-700.

Gonçalves R.C., Viana L., Sequeira J.L., Bandarra E.P., Chiacchio S.B. \& Kuchembuck M.R.G. 2001. Aspectos clínicos, anatomopatológicos e epidemiológicos da polioencefalomalacia em bovinos na região de Botucatu, SP. Vet. Notícias 7:53-57

González F.H.D. 2001. Composição bioquímica do leite e hormônios da lactação, p.5-21. In: Ibid. (Ed), Uso do Leite para Monitorar a Nutrição e o Metabolismo de Vacas Leiteiras. UFRGS, Porto Alegre, RS

Gould D.H. 2000. Update on sulfur-related polioencephalomalacia. Vet. Clin. N. Am., Small Anim. Pract. 16(3):481-496. <http://dx.doi.org/10.1016/ S0749-0720(15)30082-7><PMid:11084988>

Gould D.H., Mcallister M.M., Savage J.C. \& Hamar D.W. 1991. High sulfide concentrations in rumen fluid associated with nutritionally induced polioencephalomalacia in calves. Am. J. Vet. Res. 52(7):1164-1169. <PMid:1892274>

Hamlen H., Clark E. \& Janzen E. 1993. Polioencephalomalacia in cattle consuming water with elevated sodium sulfate levels: a herd investigation. Can. Vet. J. 34(3):153-158. <PMid:17424182>

Haven T.R., Caldwell D.R. \& Jensen R. 1983. Role of predominant rumen bacteria in the cause of polioencephalomalacia (cerebrocortical necrosis) in cattle. Am. J. Vet. Res. 44(8):1451-1455. <PMid:6625295>

Haydock D. 2003. Sulfur-induced polioencephalomalacia in a herd of rotationally grazed beef cattle. Can. Vet. J. 44(10):828-829. <PMid:14601680>
Jeffrey M., Duff J.P., Higgins R.J., Simpson V.R., Jackman R., Jones T.O., Mechie S.C. \& Livesey C.T. 1994. Polioencephalomalacia associated with the ingestion of ammonium sulphate by sheep and cattle. Vet. Rec. 134(14):343-348. <http://dx.doi.org/10.1136/vr.134.14.343> <PMid:8017015>

Klasing K.C., Goff J.P., Greger J.L. \& King J.C. 2005. Mineral Tolerance of Animals. 2nd ed. National Academics Press, Washington, D.C, p.378-382.

Kul O., Karahan S., Basalan M. \& Kabakci N. 2006. Polioencephalomalacia in cattle: a consequence of prolonged feeding barley malt sprouts. Transbound. Emerg. Dis. 53(3):123-128. <PMid:16533327>

Lemos R.A.A., Nakazato L., Barros C.S.L., Gattass C.B.A. \& Bonila R. 1997. Meningoencefalite eosinofílica em bovinos no estado de Mato Grosso do Sul. Anais 10 ${ }^{a}$ Reunião Anual do Instituto Biológico, São Paulo, SP, p.43.

Loneragan G.H., Gould D.H., Callan R.J., Sigurdson C.J. \& Hamar D.W. 1998. Association of excess sulfur intake and an increase in hydrogen sulfide concentrations in the ruminal gas cap of recently weaned beef calves with polioencephalomalacia. J. Am. Vet. Med. Assoc. 213(11):1599-1604, 1571. <PMid:9838961>

McKenzie R.A., Carmichael A.M., Schibrowski M.L., Duigan S.A., Gibson J.A. \& Taylor J.D. 2009. Sulfur-associated polioencephalomalacia in cattle grazing plants in the family Brassicaceae. Aust. Vet. J. 87(1/2):27-32. <http://dx.doi. org/10.1111/j.1751-0813.2008.00387.x><PMid:19178473>

Moro L., Nogueira R.H.G., Carvalho A.U. \& Marques D.C. 1994. Relato de três casos de poliencefalomalacia em bovinos. Arq. Bras. Med. Zootec. 46(4):409-416.

Nakazato L., Lemos R.A.A. \& Riet-Correa F. 2000. Polioencefalomalacia em bovinos nos estados de Mato Grosso do Sul e São Paulo. Pesq. Vet. Bras. 20(3):119-125. <http://dx.doi.org/10.1590/S0100-736X2000000300006>

Niles G.A., Morgan S.E. \& Edwards W.C. 2000. Sulfur-induced polioencephalomalacia in stocker calves. Vet. Hum. Toxicol. 42(5):290-291. <PMid:11003122>

Niles G.A., Morgan S.E., Edwards W.C. \& Lalman D. 2002. Effects of dietary sulfur concentrations on the incidence and pathology of polioencephalomalacia in weaned beef calves. Vet. Hum. Toxicol. 44(2):70-72. <PMid:11931505>

Nogueira A.P.A., Souza R.I.C., Santos B.S., Pinto A.P., Ribas N.L.K.S., Lemos R.A.A. \& Sant'Ana F.J.F. 2010. Polioencefalomalacia experimental induzida por amprólio em bovinos. Pesq. Vet. Bras. 30(8):631-636. <http://dx.doi. org/10.1590/S0100-736X2010000800004>

Olkowski A.A. 1997. Neurotoxicity and secondary metabolic problems associated with low to moderate levels of exposure to excess dietary sulphur in ruminants: a review. Vet. Hum. Toxicol. 39(6):355-360. <PMid:9397506>

Olkowski A.A., Gooneratne S.R., Rousseaux C.G. \& Christensen D. 1992. Role of thiamine status in sulphur induced polioencephalomalacia in sheep. Res. Vet. Sci. 52(1):78-85. <http://dx.doi.org/10.1016/0034-5288(92)90062$7><$ PMid:1553440>

Ortolani E.L. 2001. Sulphur deficiency in dairy calves reared on pasture of Brachiaria decumbens. Ciência Rural 31(2):257-261. <http://dx.doi. org/10.1590/S0103-84782001000200011>

Pearson E.G. \& Kallfelz F.A. 1982. A case of presumptive salt poisoning (water deprivation) in veal calves. Cornell Vet. 72(2):142-149. <PMid:7083863>

Radostits O.M., Gay C.C., Blood D.C., Hinchcliff K.W. \& McKenzie R.A. 2002. Doenças especificas de etiologia incerta, p.1594-1643. In: Ibid. (Eds), Clínica Veterinária: um tratado de doenças de bovinos, ovinos, suínos, caprinos e equinos. 9a ed. Guanabara Koogan, Rio de Janeiro.

Ramos J.J., Ferrer L.M., García L., Fernández A. \& Loste A. 2005. Polioencephalomalacia in adult sheep grazing pastures with prostrate pigweed. Can. Vet. J. 46(1):59-61. <PMid:15759830>

Riet-Correa R., Dutra F., Easton C., Lemos R.A. \& Rivero R. 2007. Polioencephalomalacia. XXXV Jornadas Uruguayas de Buiatría, p.191-198.

Rissi D.R., Oliveira F.N., Rech R.R., Pierezan F., Lemos R.A.A. \& Barros C.S.L. 2006. Epidemiologia, sinais clínicos e distribuição das lesões encefálicas 
em bovinos afetados por meningoencefalite por herpesvírus bovino-5. Pesq. Vet. Bras. 26(2):123-132. <http://dx.doi.org/10.1590/S0100736X2006000200010>

Sager R.L., Hamar D.W. \& Gould D.H. 1990. Clinical and biochemical alterations in calves with nutritionally induced polioencephalomalacia. Am. J. Vet. Res. 51(12):1969-1974. <PMid:1964770>

Sant'Ana F.J.F., Nogueira A.P.A., Souza R.I.C., Cardinal S.G., Lemos R.A.A. \& Barros C.S.L. 2009a. Polioencefalomalacia experimental induzida por amprólio em ovinos. Pesq. Vet. Bras. 29(9):747-752. <http://dx.doi.org/10.1590/ S0100-736X2009000900012>

Sant'Ana F.J.F., Rissi D.R., Lucena R.B., Lemos R.A.A., Nogueira A.P.A. \& Barros C.S.L. 2009b. Polioencefalomalacia em bovinos: epidemiologia, sinais clínicos e distribuição das lesões no encéfalo. Pesq. Vet. Bras. 29(7):487497. <http://dx.doi.org/10.1590/S0100-736X2009000700002>

Scarratt W.K., Collins T.J. \& Sponenberg D.P. 1985. Water deprivation-sodium chloride intoxication in a group of feeder lambs. J. Am. Vet. Med. Assoc. 186(9):977-978. <PMid:3997652>

Traverso S.D., Colodel E.M., Loretti A.P., Seitz A.L., Correa A.M., Krauspenhar C. \& Driemeier D. 2001. Polioencefalomalacia em bovinos leiteiros no Rio Grande do Sul suplementados com enxofre. Anais X Encontro Nacional de Patologia Veterinária, Pirassununga, SP, p.72.

Traverso S.D., Loretti A.P., Donini M.A. \& Driemeier D. 2004. Lead poisoning in cattle in southern Brazil. Arq. Bras. Med. Vet. Zootec. 56(3):418-421. <http://dx.doi.org/10.1590/S0102-09352004000300023> 